\title{
State forest administration performance in the Czech Republic: A case study of forestry legislation implementation in the South Bohemian Region
}

\author{
Michal Hrib ${ }^{1 *}$, Marcel Riedl ${ }^{1}$, Petra Hýsková ${ }^{1}$, Jaroslav Maršík $^{1}$, Martina Jarkovská ${ }^{2}$ \\ ${ }^{1}$ Czech University of Life Sciences Prague, Faculty of Forestry and Wood Technology, Kamýcká 129, \\ 16500 Praha - Suchdol, Czech Republic \\ ${ }^{2}$ South Bohemian Regional Authority, České Budějovice, Czech Republic
}

\begin{abstract}
In the Czech Republic, the present state forest administration is incorporated into general state administration. Municipalities with extended competence (MECs) as first-instance forest administration bodies thus perform the so-called "mixed" administration. Besides forestry, MECs cumulatively perform hunting and fishing administration, observing several different laws. On an example of three MECs in South Bohemia (České Budějovice, Týn nad Vltavou and Písek), the paper analyses the decision-making processes and control activities concerning the implementation of administrative activity, particularly the Forest Act. The findings show that during the observed period 2011-2015, the most frequently conducted administrative proceedings under the Forest Act involved binding opinions regarding permission for buildings at a distance of fewer than $50 \mathrm{~m}$ from the forest and decisions on timber harvesting. Other frequently performed acts somewhat surprisingly concerned issuing licenses for professional forest managers and decisions whether or not the land fulfils forest functions. Based on the findings, the paper also suggests stimuli and suggestions (de lege ferenda) for changes in the Forest Act and other regulations relating to this issue.
\end{abstract}

Key words: forest act; forest management guidelines; forest-related policy; municipality with extended competence; professional forest manager

\section{Introduction}

The state forest administration belongs among discussed topics and issues within forest-related policy, not only in the latitudes of the Czech Republic (Flora 2000; Drobník \& Dvořák 2010) but especially in other parts of the world (e.g. Sarvašová et al. 2013; Bizzo \& Michener 2017; Borgström 2018; Cesur \& Güloğlu 2018). Law as a part of a country's forest policy framework is an essential instrument for forest-related policy implementation (Voithleihner 2002).

The level of transparency of the state-level governments' imposed policies on forest use has been widely researched (e.g. Fuller 2006; Contreras-Hermosilla 2011; Ochieng et al. 2016; Bizzo \& Michener 2017). Researchers stress the necessity of an adaptive legal framework, which would tackle increasing uncertainties and everchanging conditions in the bioeconomy of forests (Arnold \& Gunderson 2014; Craig \& Ruhl 2014; Borgström 2018). Decision-making processes and administrative judiciary decisions affect forests' ecological and social sustainability and resource efficiency (Borgström 2018).

Analysing the legal framework and political culture in Austria, Voithleihner (2002) pointed out the need for amendments to the Austrian Forest Act and other forest regulations to overcome the shortcomings in the procedural elements of the National Forest Programme. Instead of concentrating intensely on timber production, the Austrian forestry legislation should pay attention to ecological, cultural and social goals (Voithleihner 2002). Investigating the efficiency of different-level administrative authorities in Romania, Stancioiu et al. (2010) conclude that forest administration was the most efficient at forest administrative districts and proposed financial compensation schemes for different forest ownership types. Niță (2015) discussed the forestry legislation implementation regarding its impacts on illegal logging in Romania. On the case of on-farm forests in Ghana, the (non)-compliance with the forest legislation was examined by Hansen (2011). Savchuk and Liubchych (2019) stress the absence of the legal regulation of efficient for- 
est land use and protection in Ukraine. They suggest measures considering both the applicable legislation and the public forest administration decisions (Savchuk \& Liubchych 2019).

Although there are studies on current national legislations and corresponding judicial decisions by stategovernments or state administration bodies (e.g. Bizzo \& Michener 2017; Cesur \& Güloğlu 2018), their number is still relatively low. In the context of the Czech Republic, such comprehensive analyses seem to be virtually nonexistent. To our best knowledge, such analyses could mostly be found in unpublished theses (e.g. Pelc 2015).

On an example of three bodies of the first-instance state forest administration in the South Bohemian Region of the Czech Republic (České Budějovice, Týn nad Vltavou and Písek), we analyse decision-making and control activities of the state forest administration in terms of the implementation of administrative law, in particular the Forest Act. Currently, the following regulation applies: Act No. 289/1995 Coll., on forests and on amendments to certain acts (Forest Act) (eAgri 2009a; Drobník \& Dvořák 2010).

The remaining part of this section describes the organisation of the state forest administration in the Czech Republic, with a focus on the municipalities with extended competence as the first-instance authorities and specifies this paper's objectives. In the next section, the municipalities under analysis are introduced in greater detail. Criteria of their selection, as well as the choice of the examined period, are explained. Further, the method of analysis and the steps taken in the case study are outlined. After the presentation of the results, the obtained findings are discussed. Drawing from the obtained findings and discussion, we suggest recommendations regarding eventual amendments to current legislation.

\subsection{State forest administration in the Czech Republic}

In the Czech Republic, after the public administration reform in 2000, the state forest administration was incorporated into general state administration. As a result, the then district authorities - 72 in the Czech Republic - were abolished, and smaller administrative units, the so-called municipalities with extended competence (MECs), were established. Currently, there are 205 MECs. However, the state forest administration is no longer carried out by specialists with forestry education only. Besides forestry, the administration workers at these offices cumulatively perform the hunting and fishing administration together with observance over several other laws.

As can be seen in Fig. 1, the Ministry of Agriculture, regional authorities/offices and MECs are administrative bodies that perform and ensure administrative proceedings under:
- the Forest Act No. 289/1995 Coll. (eAgri 2009a; FMI 2020),

- Act No. 149/2003 Coll., on the marketing of forest reproductive material (eAgri 2009b) and

- Act No. 226/2013 Coll., on placing timber and timber products on the market (eAgri 2009c).

They have control over implementing the laws mentioned above that specifically regulate forest management.

The Ministry of the Environment has, according to Czech law, the right of supreme state supervision, which manifests itself in the performance of practical activities of state forest administration. This is performed by the Czech Environmental Inspectorate, which focuses on forests and forest management as an environmental component of the environment. It thus supervises potential threats or damage to forests not in accordance with the regulations of forest law (Forest Act) but by considering forests as part of the environmental protection.

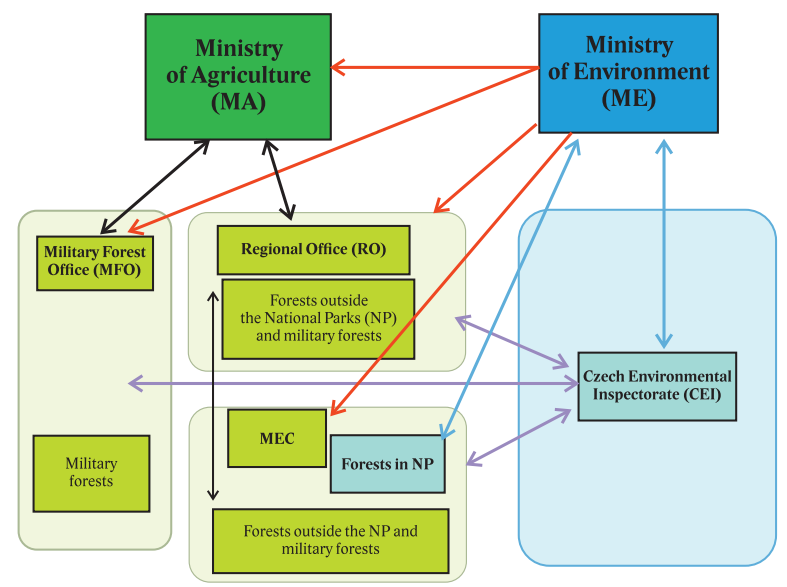

Fig. 1. Functional scheme of horizontal and vertical bodies of state forest administration (adapted from Čacká 2013).

Since the state administration reform in 2000, the general state forest administration has been organised into three levels. Thus, the state administration model is organised as a so-called "mixed" state administration (Horzinková \& Novotný 2013; Jarský \& Wild 2018). This means that the central body of the state forest administration is the Ministry of the Environment. However, the executive body is the Ministry of Agriculture. The bodies at the two lower levels are the bodies of territorial selfgovernment (regional authorities and MECs), which carry out delegated state administration.

For completeness, it is necessary to mention the deviating regime of the state forest administration in the national park forests. The state forest administration in the territory of national parks is performed through the national park administrations and the Ministry of the Environment. These include forests in four national parks with an approximate area of 90 thousand ha. In addition, a unique body of the state forest administration is the Military Forest Office, which performs state for- 
est administration in the so-called military districts - in forests inaccessible to the public, which serve military purposes and defence of the state. The area of these forests reaches approximately 125 thousand ha.

\subsection{Municipalities with extended competence}

The first-instance bodies of the state forest administration are MECs, of which there are currently 205 . The second-instance (superior and appellate) bodies are regional authorities. There are 13 regional authorities and the capital city of Prague, which has a special status and position of regional power. The highest body of the state forest administration is thus the Ministry of Agriculture, which has transferred part of its competencies to the so-called authorised person, which is the Forest Management Institute (FMI) in Brandýs nad Labem. FMI is an authorised person for legal and administrative proceedings of the state forest administration in accordance with the Act No. 149/2003 Coll., on the marketing of forest reproductive material (eAgri 2009b) and Act No. 226/2013 Coll., on placing timber and timber products on the market (eAgri 2009c).

According to Article 48 of the Forest Act, MECs make decisions in 16 different activities and provide activities and actions in another 9 agendas. Their decision-making activities include, for example:

- declaration of land as land designated to fulfil forest functions (LDFFF),

- division of forest land whose area falls below 1 ha,

- withdrawal of forest land from fulfilling forest functions and its restriction to perform forest functions,

- the decision on the amount of fees for the withdrawal,

- decision on temporary restriction on or exemption from entering the forest,

- imposition of measures deviating from the provisions of the Forest Act in the interest of special-purpose management in protective forests and special-purpose forests,

- granting or revocation of a license to perform the function of a professional forest manager,

- imposition of fines,

- imposition of measures to eliminate identified deficiencies,

- imposition of measures needed to avert imminent danger.

In addition, MECs supervise and oversee compliance with the Forest Act and regulations issued for its implementation and issue decisions on their basis. They further establish and repeal forest wardens. MECs perform state administration in all other cases unless another body of state forest administration is designated by law.

\subsection{Objectives of the paper}

The paper aims to analyse three first-instance bodies of state forest administration in the selected MECs, focusing on decision-making processes according to the Forest Act and regulations related to selected MECs. In this respect, the objective of the paper is:

1. to determine which activities the MECs deal with concerning the individual articles of the Forest Act.

The analysis of activities will also be used to verify whether the size of the MEC is proportional to the number of solved decision-making processes and the length of proceedings according to individual articles of the Forest Act. Therefore, another paper's objective is:

2. to determine whether the number of issued decisions and the duration of administrative proceedings in which the relevant decisions were issued differ significantly among the municipalities and what precisely those differences and eventual abnormal durations of administrative proceedings might depend on.

The main emphasis is on forest landowners so as not to impose a significant administrative burden on forest land ownership. Thus, drawing from the obtained results, we aim:

3. to propose stimuli and suggestions to future eventual amendments of the Forest Act in selected articles to clarify and simplify decision-making processes from the applicants' perspective.

\section{Material and methods}

\subsection{Municipalities with extended competence under analysis}

Administratively, the territory of the Czech Republic is divided into 14 higher territorial self-governing units (regions) further subdivided into 205 units, MECs. The 205 MECs perform the first-instance state forest administration.

Fig. 2 depicts the administrative division and designates the territory of three selected MECs ensuring first-instance state forest administration in the South Bohemian Region. Table 1 presents general characteristics of the three municipalities under analysis. Besides information on population, forest area, or number of cadastral territories within each MEC, information on the number of Forest Management Plans (FMP), the number of districts for which each MEC provides Forest Management Guidelines (FMG), the number of building authorities in each MEC or the number of Professional Forest Managers (PFM) is listed. 


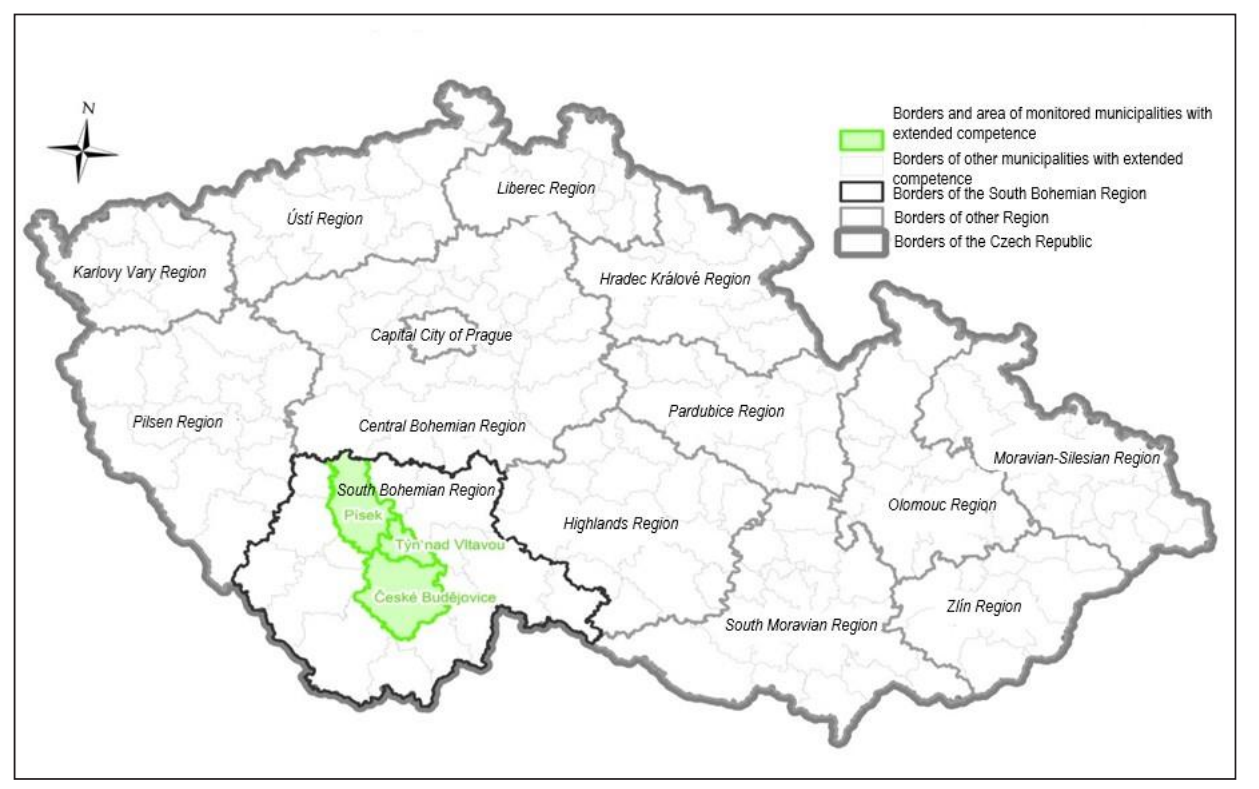

Fig. 2. Administrative division of the Czech Republic into higher territorial self-governing units (regions) and municipalities with extended competence.

The primary criterion for the selection of the firstinstance bodies of the state forest administration was the size of the municipality's territory (Jarský \& Wild 2018). Therefore, two municipalities comparable in forest area, the Statutory City of České Budějovice and the City of Písek, were selected to compare the number of judicial decisions and activities of the state forest administration bodies. The third municipality, the nearest by location to the two formerly chosen municipalities, and at the same time the smallest in the South Bohemian Region, is the City of Týn nad Vltavou, however, once part of the district of České Budějovice.

The MECs, Týn nad Vltavou and Písek, belong to Central Bohemian Uplands and the South Bohemian Basin. Both municipalities are part of the northern edge of the České Budějovice basin. The Statutory City of České Budějovice, the capital city of the South Bohemian Region, lies at the confluence of the Malše and Vltava river in the south-eastern part of the České Budějovice Basin. The MEC České Budějovice also belongs to the South Bohemian Basin.

\subsection{Method of analysis}

The data were collected from 2011till 2015. This examined period could be characterised as "the last repre- sentative" regarding the state forest administration regular operation. After 2015, Czech forestry has been highly challenged by the culminating bark beetle calamity. Since spring 2020, the activities of the state forest administration authorities have been affected by the covid-19 pandemic.

From each MEC selected for the analysis, we requested the information for all articles dealt with by the first-instance state forest administration bodies within the framework of Act No. 289/1995 Coll., both in administrative proceedings such as decisions, statements or binding opinions, covering the period 2011-2015.

The first step was to prepare MS Excel spreadsheets in which all decision-making processes according to the individual articles of the Forest Act entrusted to the MEC as the state forest administration body of first-instance were listed. The spreadsheets were filled in with the number of decision-making processes, local investigations, and duration. The data were obtained at each MEC with the help of the MEC personnel.

Another source of information was extracted from the textual part of FMG in the entrusted area of each MEC. Finally, it was necessary to determine the duration of individual decision-making processes held by each MEC as the first-instance state forest administration body. The obtained data were evaluated and compared, and graphically processed to perform a quantitative analysis. The

Table 1. Characteristics of the municipalities with extended competence: České Budějovice, Písek and Týn nad Vltavou.

\begin{tabular}{lccc}
\hline Characteristics / Municipality & Ceské Budějovice & Písek & Týn nad Vtavou \\
\hline Population & 158,018 & 52,168 & 14,096 \\
Forest area [ha] & $27,177.97$ ha & $25,724.41$ ha & 7,442 ha \\
Cadastral territory & 80 & 49 & 14 \\
FMP & 36 & 38 & 20 \\
Building authorities & 6 & 5 & 1 \\
Districts for FMG & 5 & 3 & 2 \\
PFM & 12 & 8 & 4 \\
\hline
\end{tabular}


exact wording of individual articles of the Forest Act (FMI 2020) and the commentaries on the individual articles and paragraphs were used (Drobník \& Dvořák 2010).

The last step was the overall evaluation of the results and comparison of all selected MECs in the area, the number of decision-making processes, the duration of individual decision-making processes, and the number of successful and unsuccessful appeals of separate decisionmaking processes. Furthermore, stimuli and suggestions for possible future legislative changes were suggested.

\section{Results}

\subsection{Results of the decision-making processes analysis}

The analysis revealed that all three MECs issued the highest number of binding opinions on Article 14 of the Forest Act, i.e. $31.8 \%$ of the total transmitted data. Many decisions and statements were issued for Article 33 (20.7\%), followed by Article 37 (6.9\%) and Article 3 (4.5\%). Contrastingly, Articles 17, 12, 51, 20, 19 and 22 presented a marginal issue for the state forest administration body's decision-making activity in all three MECs. The number of administrative proceedings conducted in terms of these articles occupied only tenths of a per cent of the total decision-making processes (Table 2).

In the three monitored MECs, a total of 2,681 decision-making processes were resolved over five years. The decision-making processes in question were decisions, statements and binding opinions. This is further shown in Fig. 3, which addresses the division of the processes into individual years per each MEC.

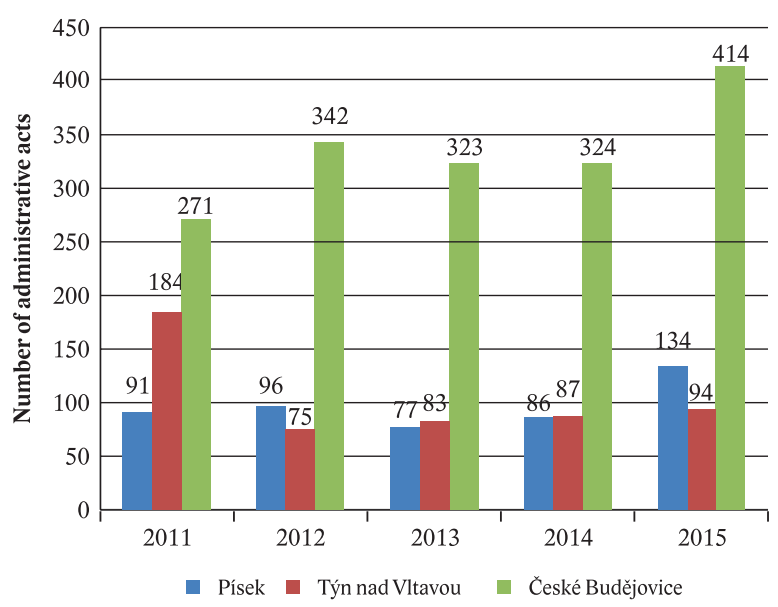

Fig. 3. The number of administrative acts issued within the state forest administration by individual first-instance bodies (offices) in Písek, Týn nad Vltavou and České Budějovice in 2011-2015.

The number of decisions at the MECČeskéBudějovice and Týn nad Vltavou corresponds to the municipalities' forest area, the number of owners and the number of processed decisions. At the MEC Písek, the number of decisions is lower than at the municipality Týn nad Vltavou. Yet in terms of a total forest area, the numbers of decisions processed at the municipality Písek might be expected to correspond to the number of decisions processed at the municipality České Budějovice. The significantly higher number of the decisions processed at the municipality České Budějovice, which is of comparable size to the municipality Písek, could be reasoned by the fact that České Budejovice is the capital city of the South Bohemian Region. There are many forest land-

Table 2. The number of decisions, statements and binding opinions on individual sections of the Forest Act.

\begin{tabular}{|c|c|c|c|}
\hline Articles in the Forest Act & Administrative activity the article relates to & \multicolumn{2}{|c|}{$\begin{array}{l}\text { Number of decisions } \\
\text { or binding opinions }\end{array}$} \\
\hline Article 3 & Decision in doubt as regards the status of land as LDFFF and declaration of land as LDFFF & 119 & $4.4 \%$ \\
\hline Article 12 & Division of plots of forest land where the area of one part of the divided land falls below 1 ha & 86 & $3.2 \%$ \\
\hline Article 14 & $\begin{array}{l}\text { Issuing binding opinions for site plans pursuant to the Construction Act, location of buildings in the protection zone } \\
\text { up to a distance of } 50 \mathrm{~m} \text { from the edge of the forest }\end{array}$ & 838 & $31.3 \%$ \\
\hline Article 17 & $\begin{array}{l}\text { Decision on withdrawal of the estate from LDFFF, on the withdrawal of forest land performing forest functions up to } \\
\text { an area of } 1 \text { ha or on the restriction of their use (temporary or permanent) }\end{array}$ & 88 & $3.3 \%$ \\
\hline Article 19 & $\begin{array}{l}\text { Use of the Forest - decision on temporary restriction or exclusion of access to the forest for reasons of protection or } \\
\text { health and safety of citizens }\end{array}$ & 13 & $0.5 \%$ \\
\hline Article 20 & $\begin{array}{l}\text { Prohibition of Certain Activities in the Forest - decision on exemptions from the ban on certain forest activities, setting } \\
\text { additional conditions in the case of organizing mass or sports events in the forests }\end{array}$ & 37 & $1.4 \%$ \\
\hline Article 22 & $\begin{array}{l}\text { Safety of Persons and Property - decision imposing measures to ensure the safety of persons and property against } \\
\text { damage that could be caused by falling rocks, landslides, falling trees and avalanches from forest lands and who will } \\
\text { bear the costs involved }\end{array}$ & 3 & $0.1 \%$ \\
\hline Article 33 & $\begin{array}{l}\text { Timber Harvesting - issuing statements on the intention to carry out logging in the forest in the case of forest owners } \\
\text { without protocol-based FMG, if the logging on these forest plots is to exceed } 3 \text { cubic meters per hectare per year, issu- } \\
\text { ing decisions on an exemption from the ban on intentional felling in stands under the age of } 80\end{array}$ & 545 & $20.0 \%$ \\
\hline Article 37 & $\begin{array}{l}\text { Forest Manager (Professional Forest Manager), changes in the person of PFM, decision to grant or revoke a license to } \\
\text { perform a function of PFM, decision to entrust a legal or natural person with the performance of a function of PFM, } \\
\text { Supervision in Forestry Activities - a decision on the imposition of measures to eliminate the identified deficiencies, }\end{array}$ & 182 & $6.8 \%$ \\
\hline Article 51 & $\begin{array}{l}\text { measures to improve the condition of forests and the fulfilment of their functions, on the cessation or reduction of } \\
\text { production or other activities in the forest in cases of imminent damage }\end{array}$ & 59 & $2.2 \%$ \\
\hline $\begin{array}{l}\text { Other opinions } \\
\text { and comments }\end{array}$ & & 711 & $26.5 \%$ \\
\hline $\begin{array}{l}\text { Decision-making } \\
\text { processes in total }\end{array}$ & & 2,681 & $100.0 \%$ \\
\hline
\end{tabular}


Table 3. Total indicators for individual municipalities with extended competences under analysis.

\begin{tabular}{|c|c|c|c|c|c|c|}
\hline \multirow{2}{*}{ MEC } & \multirow{2}{*}{ Decisions and binding opinions } & \multirow{2}{*}{ Forest area (in ha) } & LDFFF with FMP & LDFFF with FMG & \multirow{2}{*}{ Districts for FMG } & \multirow{2}{*}{ Owners in FMC } \\
\hline & & & \multicolumn{2}{|c|}{ [ha] } & & \\
\hline České Budějovice & 1,631 & $27,177.97$ & $19,043.93$ & $7,447.88$ & 5 & 4,559 \\
\hline Písek & 484 & $25,724.41$ & $21,171.77$ & $3,620.45$ & 3 & 2,316 \\
\hline Týn nad Vltavou & 523 & 7,442 & $4,981.99$ & $1,288.32$ & 2 & 1,043 \\
\hline Total & 2,638 & $60,344.38$ & $45,197.69$ & $12,356.65$ & 10 & 7,918 \\
\hline
\end{tabular}

owners with a relatively low area of forest land per owner (Table 3).

During the monitored period 2011-2015, at the MEC Písek, $85 \%$ of FMG were transferred to forest owners. For example, as a result, there is no need to issue an opinion pursuant to Article 33 on timber harvesting. At the other two municipalities, the MEC České Budějovice and MEC Týn nad Vltavou, only $5 \%$ of the FMG were transferred to forest owners. Thus, the MEC Písek did not deal with so many decision-making processes as the other two MECs. The employees of the MEC Písek were able to spend more time in the field and resolve issues directly in the terrain and inspect them subsequently. This fact was confirmed by the number of on-site verification performed.

It is evident from Fig. 4 that the issuance of binding opinions pursuant to Article 14, Paragraph 2 of the Forest Act makes up approximately one third to half of all administrative acts issued in individual years at the MEC České Budějovice. At the MEC Písek, the binding opinions amounted to $10 \%$ and at the MEC Týn nad Vltavou to one third (only in 2011, it was 10\%). No significant differences were found year on year, except for the office in Písek, which experienced an almost threefold increase in the issuance of these binding opinions in 2015. This could be related to the investment construction of family houses commenced in several townships.

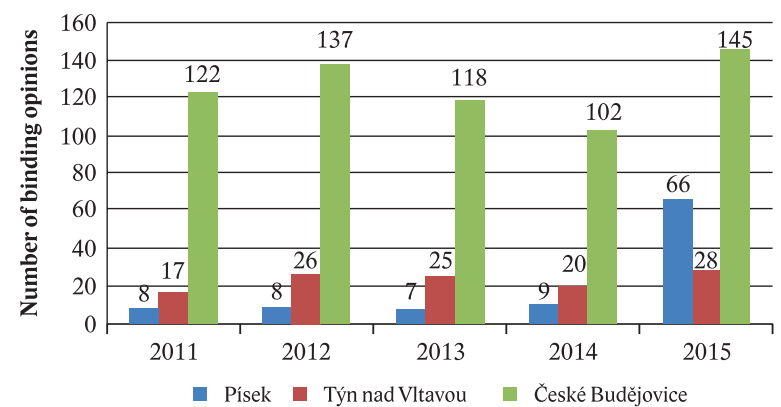

Fig. 4. Binding opinions issued pursuant to Article 14, Paragraph 2 of the Forest Act issued by first-instance bodies in Písek, Týn nad Vltavou and České Budějovice in 2011-2015.

A comparison of the issued decisions to eliminate the identified deficiencies shows that Týn nad Vltavou does not use this form of state supervision at all, Písek very sporadically (Fig. 5). It is possible that the office in České Budějovice resorted to using this tool for formalpositivist reasons. However, we would find a more precise explanation only after evaluation in connection with the resolution of offences under the Forest Act and the imposition of sanctions.

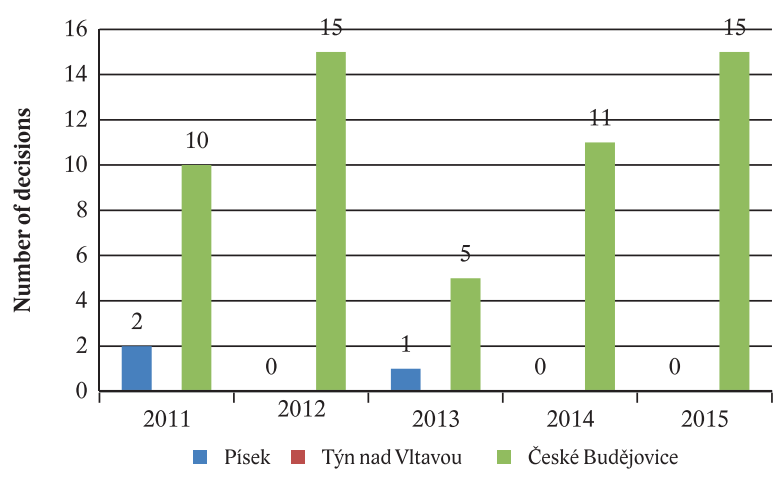

Fig. 5. Number of decisions on the imposition of measures to eliminate the identified deficiencies issued by the first instance authorities in Písek, Týn nad Vltavou and České Budějovice in 2011-2015.

Although the Forest Act has relevant provisions for the imposition of sanctions for infringements (Article 53-56, offences), this was neither monitored not evaluated. At the MEC České Budějovice, the solution of offences under the Forest Act is not discussed by the state forest administration, but by a special department that solves offences for other branches of environmental law as well.

Having compared all 2,681 decision-making processes carried out at the three MECs Písek, České Budějovice and Týn nadVltavou, we divided the decisionmaking processes into several sets referring to particular issues. We first selected those Articles which directly solve the issue of LDFFF. This includes Articles 3, 12, 14 and 17 . In this respect, $42.2 \%$ of all decisions, statements and binding opinions were issued. The second set refers to the activities performed on the LDFFF (Articles 19, 20, 22 and 33) (22.3\%). The third set concerns the PFM and other binding opinions and statements (Article 37) (33.3\%). The fourth set concerns supervision (Article 51). Regarding the control and imposition of measures to eliminate identified deficiencies, only $2.2 \%$ of all administrative proceedings were carried out.

In the analysed period 2011-2015, 23 appeals were registered at the three examined MECs. One appeal was issued at the MEC České Budějovice and twenty-two appeals at the MEC Týn nad Vltavou. These included 15 appeals to Article 37, 2 appeals to Article 19 and 1 appeal to Article 16 of the Forest Act. Given the total number of decisions, statements and binding opinions, which amounted to 2,638 , this was rather a negligible percentage. 


\subsection{Time-line analysis and duration of the decision-making processes}

Fig. 6 presents the annual frequency distribution of settled and filed administrative acts at the MEC České Budějovice between 2011 and 2013. The proportional frequencies did not change significantly during individual months, with two exceptions. A slight absolute increase in the administrative activities can be observed in the autumn months, October and November. These two months are "most suitable" for logging permits applications because logging occurs mainly during periods of dormancy. Other agendas were relatively evenly distributed throughout the year. Thus, no statistically significant dependence on specific agendas under the provisions of the Forest Act was confirmed. act according to the Forest Act. From a procedural point of view, a binding opinion is a basis and part for decision-making in construction proceedings. It is not even a separate act (e.g. from the point of view of appeals). Currently (March 2021), a draft of a new building law is being submitted to the Parliament of the Czech Republic in the form of a legislative discussion. This proposal also envisages a new and more efficient procedural modification of the construction procedure.

Similarly, even some of the submitted variants of amendments propose to exclude the issuance of the current binding opinion from the state forest administration body's competence and transfer this decision-making to the competence of building authorities. Thus, from the practical point of view of the activities of the state forest

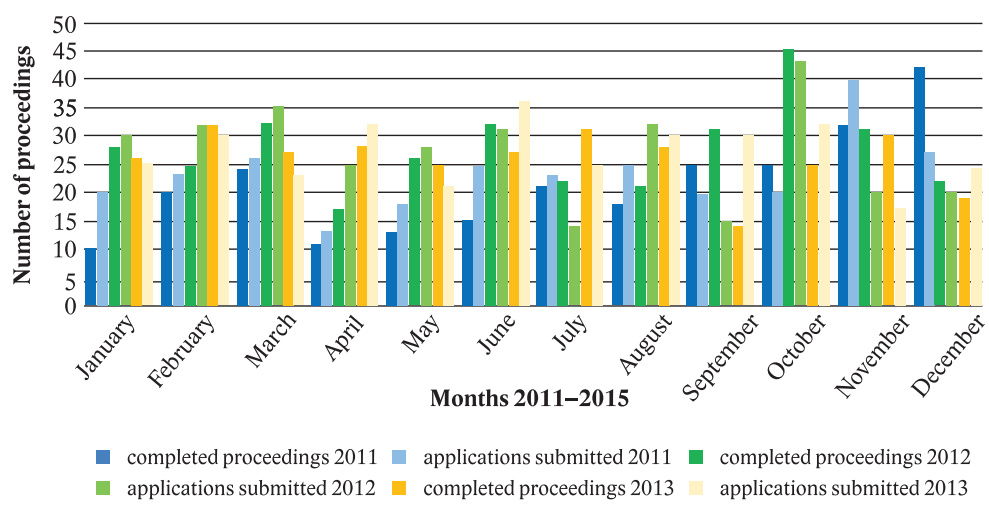

Fig. 6. The time-line of completed proceedings and applications submitted between 2011-2013 in the municipality with extended competence České Budějovice.

The length of ongoing proceedings in all three surveyed municipalities varied. At all three MEC offices, the average length of individual proceedings was around 30-60 days. The longest average time for individual types of proceedings was monitored at the MEC Písek - 55 days. In the case of issuing binding opinions pursuant to Article 14, Paragraph 2, the average time for issuing an opinion at MEC České Budějovice was 19 days, Týn nad Vltavou 27 days and MEC Písek 33 days. On the other hand, Písek proved to be the most "thorough" in monitoring the number of local investigations. The municipality carried out local investigations for individual types of administrative proceedings - i.e. investigating the situation on the spot. It is possible that due to this practice, the average length of administrative proceedings was extended compared to the other two monitored authorities.

\section{Discussion}

The research clearly shows that the issuance of a binding opinion pursuant to Article 14 Paragraph 2 on the location of buildings located at a distance of $50 \mathrm{~m}$ from the MEC's forest was the predominant administrative administration, the part of primarily administrative decision-making could be "dropped" in the future. Such an administrative act's correct and error-free performance is not directly conditioned by highly specialised forestry qualification. State forest officials would eventually be given time to focus on other professional forestry administrative and control activities, e.g., forest protection.

Regarding the buildings situated up to $50 \mathrm{~m}$ from the edge of the LDFFF, the law addresses this issue very benevolently and does not limit where buildings can be located. Instead, the law states that facilities should not be located in the $50 \mathrm{~m}$ zone from the forest's edge. This could be explained in many ways. It is not possible to enforce a limit set for all cases in general. This issue is better addressed, for example, in the Saxon Forestry Law of $10^{\text {th }}$ April 1992 (SächsWaldG 2020). We agree with Vančura (2009) that the provisions of Article 25 of the Saxon Forestry Law (SächsWaldG 2020) prevent imminent damage, including restrictions on the management of neighbouring land so that the forest owner is obliged to comply with new forest.

In line with our findings, the investigation (Pelc 2015) performed in 2008-2012 at six MECs in 6 different regions across the $\mathrm{Czech}$ Republic also confirmed the 
absolute predominance of issuing binding opinions pursuant to Article 14 (2). These binding opinions accounted for $50 \%$ of all administrative acts. The other most frequent decisions were descendingly related to Articles 3 , 12, 17 (in connection with Articles 13-16) and Article 51. While in our investigation, no proceedings were conducted pursuant to Article 34 for the transport of timber over the forest estates of other owners, in the case of Pelc's investigation, these proceedings were conducted, but also very marginally ( $0.3 \%$ frequency).

Contrary to our findings, decisions under Article 33 (opinion on logging and logging permits) were less frequent in Pelc's investigation than proceedings for land withdrawal or a decision in doubt on LDFFF. The lower frequency of decision-making according to Article 33 could be related to the frequency of occurrence of untransferred FMG and the share of small forest owners in the area of competence of individual MECs. Contrary to our results, the duration of individual proceedings was, on average, one week shorter (Pelc 2015).

Unfortunately, other research results that would deal with similar issues and could be compared in terms of the survey methodology are unavailable, at least in the Czech Republic. Research results on forestry law implementation in other countries suggest amendments to exiting legislation (e.g. Stancioiu et al. 2010; Hansen 2011; Niţă 2015; Cesur \& Güloğlu 2018; Savchuk \& Liubchych 2019), which could warrant further research and careful evaluation (Cesur \& Güloğlu 2018). As one of the possible implications of this study, the results could be used in a multi-national comparative analysis of forestry laws and other regulations.

One of the significant deficiencies and disadvantages of the current "mixed" model of state forest administration is the systemic conflict of interest of state forest administration employees, de facto MECs' employees. However, these municipalities (cities) are, at the same time, the owners of forest property and state administration employees have to exercise state supervision on this property entirely independently. In practice, this means that according to the Forest Act, they are competent to impose a sanction for an illegal act or to impose measures to eliminate the identified deficiencies in the property of their employer. In our specific case, this means that the town of Písek owns an extensive forest property with an area of 6,270 ha, the town of České Budějovice owns forests with an area of 1,766 ha and Týn nad Vltavou forests with an area of 343.28 ha (Jarský \& Wild 2018). Numerous authors discuss this system mismatch (e.g., Horzinková and Novotný (2013). It is suggestive that separating state forest administration from self-government could solve the problem. This systemic discrepancy could disappear with the establishment of separate specialised forest authorities.

A new strategic material adopted by the Government of the Czech Republic in 2020, entitled "The concept of state forest policy until 2035” (eAgri 2020), envisages the reform of the state forest administration. Similarly, it views it as plausible to separate state forests from the general state administration and establishing specialised state forest administration. Thus, specialized forest authorities are already being discussed.

In the case of our investigations, the issue of proceedings on the granting (or revocation) of a PFM's license and on the payment of compensation provided by the state for the performance of the PFM's function proved to be a regionally topical issue within the scope of individual MECs. Our investigation also reflected that legal disputes in the South Bohemian region took place before the administrative courts, which resolved the inconsistency in interpreting the relevant legal provisions.

The legislative body (the Parliament of the Czech Republic) later reacted to this by issuing the amendment to the Forest Act No. 314/2019 Coll., which amended the previous wording of Act No. 289/1995 Coll., On Forests and on Amendments to Certain Acts (Forest Act) and with effect from $29^{\text {th }}$ November 2019, extended the provisions of the Forest Act to the PFM by new Articles 8 to 10, which supplemented the existing Forest Act by: - An exhaustive list of the essential duties of a PFM, whose activities are paid for by the state

- Exemplary (demonstrative) list of professional acts and activities of a PFM, which were mentioned in the previous paragraph.

- Clarification of the list of obligations that apply to a PFM whose activities are paid for by the forest owner. Drawing from the findings and the discussion, our further proposals de lege ferenda consist in separating the state forest administration from the general state administration, establishing specialised state forest administration (forest authorities), transferring competencies according to Article 14 (2) to the Construction Act and introducing mandatory examination for a PFM to obtain a licence.

We are aware that the results of our analysis can neither be generalised nor regarded as conclusive. They reflect administrative proceedings of three state administration authorities in one region only. Despite this, the obtained findings could still confirm a similar situation in other regions nationwide (Pelc 2015) regarding decisionmaking processes and administrative acts performed by the first-instance forest administration offices.

\section{Conclusion}

The paper's objective was to analyse the activities of the first-instance body of the state forest administration, focusing on the activities related to individual articles and paragraphs of the Forest Act. The data were analysed from three subjects of the state forest administration municipalities with extended competence. For the analysis of the decision-making activities of the state forest administration body, a representative period from 2011 
to 2015 was chosen. The findings revealed that by far the most predominantly issued act was a binding opinion pursuant to Article 14 Paragraph 2 of the Forest Act on the location of buildings in the protection zone up to a distance of $50 \mathrm{~m}$ from the edge of the forest. The findings further point to the necessity to lift an administrative burden from the first-instance body officials and forest landowners and the relative ineffectiveness of the current "mixed" state administration.

The paper strives to answer a relatively simple question as to which administrative acts according to the Forest Act are the most frequented and whether they represent nationwide or only local trends. Despite the assumed simplicity of the paper's objective, the research presents relatively unique findings. No such comprehensive study on the proceedings of the state forest administration has been carried out to this date. There exists a rich body of scholarly literature on governance or "friendly" state administration; however, for the solution of future reform of the state forest administration in the Czech Republic, raw data of this kind are missing. Although our research has concentrated on a limited period and one region of the Czech Republic only, it can still contribute to an overall picture of state forest administration's functioning onsite. For the future state forest administration reform, it would be plausible to have as much up-to-date data. Other, more comprehensive, in-depth and state-of-art analyses reflecting its current state and condition would be beneficial as possible stimuli for possible legislative amendments and as an impetus for future research in this field.

\section{Acknowledgements}

This publication was supported by the Czech National Agency for Agricultural Research under contract no. NAZV QK1920272 entitled "Communication as a tool to harmonise the needs of society and the forestry sector" and implemented as a result of a project LD15126 "Analysis of forest-related policy in the Czech Republic as a tool for the orchestration of forest-related policy in Europe" supported by the Czech Ministry of Education, Youth and Sports.

\section{References}

Arnold, C., Gunderson, L., 2014: Adaptive Law. In: Craig, R. A., Ahjound, S. G. (eds.): Social Resiliance and Law. Columbia University Press, New York.

Bizzo, E., Michener, G., 2017: Forest Governance without Transparency? Evaluating state efforts to reduce deforestation in the Brazilian Amazon. Environmental Policy and Governance, 27:560-574.

Borgström, S., 2018: Reviewing natural resources law in the light of bioeconomy: Finnish Forest regulations as a case study. Forest Policy and Economics, 88:11-23.
Cesur, I., Güloğlu, Y., 2018: Judicial Review of Mining Exploration-Expoitation Licence- Permits and Revocations in Forest Areas. Kastamonu University, Journal of Forestry Faculty, 18:366-375.

Contreras-Hermosilla, A., 2011:People, governance and forests - the stumbling blocks in forest governance reform in Latin America. Forests, 2:168-199.

Craig, R., Ruhl, J. B., 2014: Designing administrative law for adaptive management. Vanderbilt Law Review, 67(1).

Čacká, J., 2013: Státní správa lesů (State forest administration). Bachelor thesis. University of Finance and Admisnitration, Karlovy Vary, 78 p.

Drobník, J., Dvořák, P., 2010: Lesní zákon: komentář (Forest Act: Commentary). $1^{\text {st }}$ ed. Prague, WoltersKluwer, $290 \mathrm{p}$.

Flora, M., 2000: Základní principy lesního práva v sousedních zemích - XIII (Basic Principles of Forest Law in neighbouring countries - XIII). Lesnická práce. 79(1).

Fuller, D. O., 2006: Tropical forest monitoring and remote sensing: a new era of transparency in forest governance? Singapore Journal of Tropical Geography, 27:15-29.

Hansen, C. P., 2011: Forest law compliance and enforcement: The case of on-farm timber extraction in Ghana. Journal of Environmental Management, 92:575-586.

Horzinková, E., Novotný, V., 2013: Základy organizace veřejné správy v ČR (Basics of public administration organization in the Czech Republic). $3^{\text {rd }}$ ed. Pilsen: Vydavatelství a nakladatelství Aleš Čeněk, 248 p.

Jarský, V., Wild, J., 2018: Ownership of forests by natural persons. A set of specialized maps with professional content. Local and city owners. Available at http:// vlastnictvilesu.cz/doc/mapa-lokalni_a_ve_meste_ bydlici.pdf [Accessed 31 March, 2021].

Niţă, M.A., 2015: The impact of national and EU legislative framework on the illegal exploitation of forests in Romania. A managerial cause-effect approach. Procedia Economics and Finance, 32:784-789.

Ochieng, R. M., Visseren-Hamakers, I. J., Arts, B., Brockhaus, M., Herold, M., 2016: Institutional Effectiveness of REEDD + MRV: countries progress in implementing technical guidelines and good governance requirements. Environmental Science and Policy, 61:42-52.

Pelc, J., 2015: Analýza činnosti prvostupňového orgánu státní správy lesů zejména s ohledem na údaje a vedení lesní hospodářské evidence. Master's thesis. Czech University of Life Sciences Prague.

Sarvašová, Z., Dobšinská, Z., Šálka, J., 2013: Public participation in sustainable forestry: the case of forest planning in Slovakia. iForest, 7:414-422. 
Savchuk, O.,Liubchych,A., 2019: Legislative framework for the development of innovative infrastructure of efficient use and protection of land under forest shelter belt plantations. Sci. innov., 15:5-13.

Stancioiu, P.T., Abrudan, I. V., Dutca, I., 2010: The Natura 2000 ecological network and forests in Romania: implications on management and administration. International Forestry Review, 12:106-113.

Vančura, K., 2009: Lesní hospodářství Saska (Forestry of Saxony). Lesnická práce, 88(7).

Voitleithner, J., 2002: The National Forest programme in the light of Austria's law and political culture. Forest Policy and Economics, 4:313-322.

\section{Other sources}

eAgri, 2009a:Zákon č. 289/1995 Sb., o lesích a o změněa doplněníněkterýchzákonů. On forests and on amendments to certain acts). Available at: http://eagri.cz/ public/web/mze/vyhledavani/index\$41111.html?qu ery $=289 \% 2 \mathrm{~F} 1995+\&$ segments=eagri. [Accessed 31 March, 2021].

eAgri, 2009b: Zákon č. 149/2003 Sb., o uvádění do oběhu reprodukčního materiálu Available at: http://eagri.cz/public/web/mze/lesy/dotacev-lesnim-hospodarstvi-a-myslivosti/podporagenofondu-lesnich-drevin/souvisejici-legislativa/ narodni-legislativa-a-strategie/zakon-c-149-2003sb-o-uvadeni-do-obehu.html [Accessed 31 March, 2021].
eAgri, 2009c: Zákon č. 226/2013 Sb., o uvádění dřeva a dřevařských výrobků na trh. Available at: http://eagri. $\mathrm{cz} /$ public/web/mze/vyhledavani/index\$41111.htm l?query $=226 \% 2 \mathrm{~F} 2013 \&$ segments=eagri.mze.lesy [Accessed 31 March, 2021].

eAgri, 2020: Koncepce státní lesnické politiky do roku 2035. Available at: http://eagri.cz/public/web/ file/646382/Koncepce_statni_lesnicke_politiky_ do_roku_2035.pdf [Accessed $31 \mathrm{March}, 2021]$.

FMI, 2020: Act dated 3 November 1995 on Forests and Amendments to some Acts (the Forest Act) Act No. 289/1995 Coll. Available at: http://www.uhul.cz/ images/ke_stazeni/legislativa_jazyky/Lesni_zakon_ en.pdf [Accessed 31 March, 2021].

SächsWaldG, 2020: Waldgesetz für den Freistaat Sachsen vom 10. April 1992, SächsWaldG (Forest Act for the Free State of Saxony of $10^{\text {th }}$ April, 1992, Saxony Forestry Law). Available at: https://www.revosax. sachsen.de/vorschrift_gesamt/5405/38726.html [Accessed 15th May, 2021]. 